\title{
Ewolucja poglądów Juliana Haynesa Stewarda na temat ekologii kulturowej
}

\section{Wprowadzenie}

Julian Haynes Steward - jeden z najwybitniejszych antropologów amerykańskich XX wieku - urodził się w roku 1902 w Waszyngtonie. Studiował kolejno w Deep Springs College w Kalifornii, na Uniwersytecie Cornell oraz Uniwersytecie Kalifornijskim w Berkeley, gdzie uzyskał doktorat $\mathrm{z}$ antropologii w roku 1929. Prowadził liczne badania terenowe i pracował jako nauczyciel akademicki na wielu uczelniach. Był zatrudniony w American Bureau of Ethnology i był dyrektorem Insitut of Social Anthropology, po czym ponownie wrócił do pracy dydaktycznej. Wykładał na Uniwersytecie Columbia, a następnie na Uniwersytecie Illinois w Urbana-Champaign. Zmarł w Champaign w roku 1972 tydzień po swoich siedemdziesiątych urodzinach.

Postać Juliana Stewarda najczęściej łączona jest z materialistycznym i neoewolucyjnym ujęciem antropologii. Powszechnie uważa się go za twórcę ekologii kulturowej, która w latach pięćdziesiątych i sześćdziesiątych XX w. zdominowała amerykańską szkołę antropologiczną. Najogólniej można ją określić jako systematyczne badanie wzajemnych zależności czynników środowiska, technologii i zachowania się człowieka. Badania te prowadzone są przy użyciu metod nauk społecznych w celu poznania procesów przystosowania i zmian określonych społeczności ze względu na wpływ właściwego im środowiska naturalnego. ${ }^{1}$ $\mathrm{Z}$ tak rozumianą ekologią kulturową lączy się też wieloliniowa ewolucja kulturowa - druga najważniejsza koncepcja naukowa Stewarda.

Myśl Stewarda tworzy swoistą syntezę historycznego partykularyzmu Boasa i Kroebera $z$ wypracowaną przez Leslie White'a koncepcją ewolucji kulturowej. Z jednej strony Steward krytykował podejścia partykularystyczne, twierdząc, że proste podobieństwa pomiędzy różnymi kulturami mogą być

1 Por. R. McC. Neting, Cultural Ecology, [w:] D. Levinson (red.), M. Ember (red.), Encyclopedia of Cultural Anthropology, New York: Henry Holt and Company 1996, Vol. 1, s. 267. 
wyjaśnione jako niezależne przystosowania w podobnych warunkach środowiskowych. $Z$ drugiej zaś strony, wskazywal, że nie wszystkie społeczności przechodzą te same stadia rozwojowe i ewolucja jednoliniowa jest koncepcją zbyt ogólną, żeby mogła być prawdziwa. Jego koncepcja ekologii kulturowej podkreśla natomiast, że nie da się w pełni zrozumieć znaczenia kulturowych i psychologicznych czynników oraz ich wpływu na kulturę, jeśli nie zrozumie się warunkującej ich ekologii.

Celem tego artykułu jest ukazanie ewolucji poglądów Stewarda na temat ekologii kulturowej. Wskazane zostaną zasadnicze inspiracje tej koncepcji oraz jej konstytutywne cechy. Zostaną zaprezentowane dwie zasadnicze wersje koncepcji Stewarda: „klasyczna” i „postklasyczna” postać ekologii kulturowej, ich wzajemne różnice i wynikające stąd konsekwencje.

\section{2. Źródła ekologii kulturowej}

Zaproponowana przez Juliana Stewarda koncepcja antropologiczna była bardzo oryginalna. Wydaje się jednak, że na jej kształt wpłynęły zarówno osobiste doświadczenia Stewarda, jak i sytuacja społeczno-ekonomiczna w ówczesnej Ameryce, a także prowadzona w tamtym czasie żywa debata naukowa. Oryginalność w sposobie ujmowania badań antropologicznych można zaobserwować u Stewarda już w latach trzydziestych i to zarówno w jego pracach teoretycznych, jak i terenowych.

Niektóre fakty z życia Stewarda miały wpływ na powstanie i rozwój ekologii kulturowej, skierowały bowiem jego uwagę na zagadnienia, które stały się istotnymi elementami jego naukowych koncepcji. Wydaje się, że źródeł jego inspiracji należy poszukiwać we wpływie trzech różnych środowisk: środowiska naturalnego i społecznego; środowiska rodzinnego i wychowawczego oraz środowisko intelektualnego. ${ }^{2}$

$\mathrm{Na}$ oryginalność podejścia do zagadnień antropologicznych istotny wpływ miały zdobyte przez niego doświadczenia we wczesnym okresie studiów w Deep Springs. Steward przez trzy lata stykał się tam z pracą fizyczną w surowych warunkach Kalifornii, czego nie doświadczyli jego późniejsi koledzy-antropolodzy, studiujący na wschodzie USA. Program studiów w Deep Springs College, oprócz przyswajania wiedzy teoretycznej, obejmował bowiem także zajęcia praktyczne z zakresu takich dziedzin, jak geologia, zoologia i antropologia. Steward doświadczył też skutków funkcjonowania akweduktu dostarczającego wodę z Deep Springs Valley do aglomeracji Los Angeles. Na jego oczach pozbawiona

Szerzej na temat inspiracji antropologii Juliana Stewarda pisze R. F. Sadowski w artykule Źródła antropologii Juliana Haynesa Stewarda w „Studia Ecologiae et Bioethicae” 4(2006), s. 49-60. 
wody żyzna i tętniąca życiem dolina stopniowo pustynniała. Takie czynniki, jak ziemia, woda, żywność, technologia i praca mężczyzn uformowały obszar jego intelektualnych zainteresowań i znalazły trwałe miejsce w badaniach i publikacjach Juliana Stewarda. Osobiste doświadczenia konkretnych miejsc i zdarzeń dostarczyły szablonu dla jego późniejszych badań jako antropologa. W swych publikacjach Steward wskazywał na korelacje pomiędzy gospodarką zasobami wodnymi, ekonomią i zaludnieniem pierwotnych cywilizacji. Virginia Kerns stwierdziła wręcz, że pobyt Stewarda w Deep Springs można traktować jako „laboratorium ekologii kulturowej", w którym rozwijały się i dojrzewały pomysły przedstawione przez Stewarda w najważniejszych jego publikacjach. ${ }^{3}$ Wpływ na kształt ekologii kulturowej wywarły także pewne doświadczenia społeczno-ekonomiczne. W przypadku Stewarda byly to nieustanne problemy finansowe związane $z$ wielkim kryzysem ekonomicznym panującym w USA, co zmuszało go do ustawicznego poszukiwania pracy i wielokrotnego przenoszenia się ze względu na oferowane mu posady. Podążanie za środkami utrzymania stało się później ważnym elementem ekologii kulturowej.

Silny wpływ na ukształtowanie naukowych zainteresowań Stewarda miało środowisko rodzinne i wychowawcze. Już w dzieciństwie zauważa się u Juliana głęboką niechęć do religii i polityki oraz miłość do środowiska naturalnego, co znacząco wpłynęło na kształt jego późniejszych koncepcji naukowych. Obecność lub absencja tych elementów w jego myśli antropologicznej nie jest przypadkowa, należy ją łączyć z poglądami jego rodziców i ich wzajemnymi relacjami. Istotny wpływ na poglądy Stewarda wywarły także inspiracje niektórych jego wykładowców, a szczególnie Luciena Luciusa Nunna oraz profesorów Burra i Sragera.

Znacząco na rozwój ekologii kulturowej wpłynęło także środowisko intelektualne. Wbrew zaprzeczeniom Stewarda, bezpośredni kontakt z Alfredem L. Kroeberem, Robertem H. Lowie, Edwardem W. Giffordem oraz Williamem D. Strongiem również przyczynił się do kształtowania jego poglądów. Zetknięcie się z publikacjami takich uczonych, jak C. D. Forde, C. O. Sauer, Thomas R. Malthus także miało wpływ na rozwój jego intelektualnych koncepcji. Ożywiona dyskusja w środowisku naukowym wywołana publikacją Theory of Culture Change również przyczyniła się do stopniowej zmiany ujęcia ekologii kulturowej i przejścia od wersji „klasycznej” do „postklasycznej”.

Por. V. Kerns, Scenes from the High Desert: Julian Steward's Life and Theory, Urbana-Chicago: University of Illinois Press 2003, s. 7-9. 


\section{Ewolucja koncepcji}

Analiza twórczości Stewarda, w kontekście ekologii kulturowej, usprawiedliwia wyróżnienie dwóch podstawowych etapów kształtowania się tej koncepcji. ${ }^{4}$ Wydaje się, że zasadniczy zrąb ekologii kulturowej Steward wypracował w latach trzydziestych, czterdziestych i pięćdziesiątych ubiegłego stulecia. Począwszy od późnych lat pięćdziesiątych można dostrzec wyraźną ewolucję stanowiska Stewarda polegającą na porzucaniu niektórych wcześniejszych poglądów. Pierwszy etap kształtowania się ekologii kulturowej można zatem określić jako „klasyczną" formę ekologii kulturowej, natomiast drugi etap jako formę "postklasyczną".

\section{1. „Klasyczna” ekologia kulturowa}

Ekologia kulturowa była owocem niemal czterdziestu lat studiów oraz intensywnych badań terenowych i doświadczeń życiowych Juliana Stewarda. Jego pomysły w tym względzie wyłaniały się stopniowo. Zaczątki kształtowania się koncepcji można dostrzec już w publikacjach z lat trzydziestych i czterdziestych. ${ }^{5}$ W roku 1936 ukazała się prawdopodobnie pierwsza publikacja Stewarda, podejmująca tematykę wzajemnej relacji środowiska naturalnego i szeroko pojętej kultury pierwotnych grup ludzkich. Kwestie środowiska naturalnego, strategii zdobywania pożywienia, struktur społecznych stały się od tego czasu stałym elementem badań Stewarda i stanowią istotne czynniki ekologii kulturowej. ${ }^{\circledR}$

Kolejną ważną publikacją z tego okresu była książka Basin-Plateau Aboriginal Sociopolitical Groups. ${ }^{7}$ Opierając się na badaniach terenowych wśród Pajutów i Szoszonów, Steward przedstawił bardzo drobiazgowy opis tradycyjnych spo-

\footnotetext{
Por. tamże, s. 323

5 Aż do początku lat pięćdziesiątych publikacje Stewarda przedstawiające ekologię kulturową nie spotkały się z poważniejszym zainteresowaniem środowiska naukowego. Por. tamże, s. 276.

6 Por. J. H. STEWARD, The Economic and Socal Basis of Primitive Bands, [w:] R. H. Lowie (red.), The Economic and Social Basis of Primitive Bands, Berkeley: University of California Press 1936, s. 331-350; por. także R. F. MurPHY, Introduction: The Anthropological Theories of Julian H. Steward, [w:] J. C. Steward (red.), R. F. Murphy (red.), Evolution and Ecology. Essays on Social Transformation, Urbana-Chicago-London: University of Illinois Press 1977, s. 24.

7 Książka została wydana w Waszyngtonie nakładem United States Government Printing Office w roku 1938. H. H. Turney-High wskazuje na podstawowy cel wyznaczony przez Stewarda „analizę wpływu ekologii na instytucje socjopolityczne”. Podkreśla też znaczenie i wartość książki, dostrzegając jednak pewne jej braki. Uważa za błędne użycie przez Stewarda terminu „ekologia” w znaczeniu odbiegającym od ogólnie przyjętego. Należy jednak podkreślić, że akcent, jaki Steward kładzie na czynniki ekonomiczne i rolę środowiska naturalnego, jest w tej pozycji wyraźny. Por. H. H. Turney-High, Review of Basin-Plateau Aboriginal Sociopolitical Groups by J. H. Steward, „American Anthropologist” New Series Vol. 42, No 1, 1940, s. 136-138.
} 
sobów zdobywania środków utrzymania. W rozdziale zatytułowanym Ekologia $w$ studiach kulturowych Steward przekonywał, że nie można w pełni zrozumieć znaczenia kulturowych i psychologicznych czynników i ich wpływu na kulturę, jeśli nie zrozumie się warunkującej ich ekologii. ${ }^{8}$

Dalszym krokiem na drodze do wypracowania ekologii kulturowej były badania przeprowadzone latem 1940 roku na temat plemienia Indian Carrier. W badaniach tych również dostrzegamy wyraźne elementy kształtującej się ekologii kulturowej. ${ }^{9}$ Steward wypracował wówczas podstawy tego, co później nazwał "metodą ekologii kulturowej”. Wtedy uwagę poznawczą koncentrował na środkach niezbędnych do życia, modelu pracy i technologii używanej w celu zdobycia żywności, a więc na kwestiach, które określił jako „jądro kulturowe” (cultural core).$^{10}$

Nowatorska koncepcja nie została jednak szerzej zauważona w środowisku antropologów. W uzasadnieniu przyznanej Stewardowi prestiżowej nagrody Viking Fund Award, wyliczając jego osiągnięcia, wskazano na prace z zakresu ewolucji kulturowej a nie ekologii kulturowej. Wyjaśnia to powód, dla którego Steward swojej najgłośniejszej książce Theory of Culture Change nadał podtytul The Methodology of Multilinear Evolution i odpowiednio uszeregowat kolejne jej rozdziały. Nie mogąc przez lata przebić się z ekologią kulturową, posłużył się znaną i zaakceptowaną w środowisku antropologów koncepcją ewolucji kulturowej, traktując ją jako narzędzie umożliwiające promocję swojej koncepcji. Wydaje się, że obie jego koncepcje, tzn. zarówno ekologia kulturowa, jak i wieloliniowa ewolucja kulturowa są ze sobą powiązane. ${ }^{11}$

Można stwierdzić, że ekologia kulturowa została wyraźnie sformułowana i zauważona przez środowisko antropologiczne dopiero w roku 1955 wraz z ukazaniem się książki Theory of Culture Change. Steward zebrał w niej i ponownie opublikował wszystkie najważniejsze teksty dotyczące ekologii kulturowej. Najważniejszy dla Stewarda rozdział tej książki został zatytułowany Koncepcja i metoda ekologii kulturowej, był to tekst referatu wygłoszonego w roku 1953 podczas sympozjum Ecology in Anthropology. Wystąpienie na prestiżowym sympozjum i publikacja w głośnej książce spowodowały zauważenie ekologii kulturowej oraz uznanie Stewarda za twórcę $\mathrm{i}$ architekta tej koncepcji. ${ }^{12}$

8 Por. J. H. STEWARD, Basin-Plateau Aboriginal Sociopolitical Groups, Washingtion: United States Government Printing Office 1938, s. 260.

9 Steward wskazuje na zmianę sposobu życia tego plemienia spowodowaną wprowadzeniem nowych technologii i narzędzi. Wprowadzone zmiany spowodowaly transformację struktury społecznej, powodując kolejno przejście od struktury band, do klanu a następnie do pojedynczych niezależnych rodzin przy zachowaniu dotychczasowego pożywienia. Por. J. H. STEWARD, Investigations Among The Carrier Indians in British Columbia, "The Scientific Monthly" Vol. 52, No. 3, 1941, s. 280-283.

10 Por. V. Kerns, Scenes from the High Desert..., dz. cyt., s. 219.

11 Por. Tamże, s. 276.

12 Por. Tamże. 
Steward podkreślał, że „ekologia kulturowa zwraca szczególną uwagę na te czynniki, które w wyniku analizy empirycznej wydają się być najbardziej związane $\mathrm{z}$ zagospodarowaniem środowiska naturalnego a zostały zalecone przez kulturę". ${ }^{13}$ Ekologia kulturowa mniej koncentruje się na pochodzeniu technologii niż na fakcie, że technologia może być użyta w różny sposób zależnie od środowiska naturalnego. Szczególne bowiem warunki lokalne mogą wymagać przystosowań, których konsekwencje są bardzo dalekosiężne. Przykładowo, społeczności używające takich samych narzędzi i technik łowieckich (łuki, włócznie, zagrody, wypalanie lasów i łąk, wilcze doły, ...) mogą się różnić zależnie od warunków środowiska naturalnego panujących w poszczególnych regionach oraz występującej na nim zwierzyny. Jeśli zwierzęta występują w dużych i licznych stadach, jak np. bizony czy karibu, to przewagę mają te techniki lowieckie, które prowadzą do współpracy grup złożonych z wielu myśliwych podążających za stadami. $W$ wypadku terenów pozbawionych takich stad, a obfitujących w mniejsze zwierzęta żyjące samotnie lub w nielicznych stadach, bardziej efektywne jest polowanie pojedynczego myśliwego lub kilkuosobowych grup myśliwych operujących na stałym i dobrze rozpoznanym terenie. Procesy przystosowawcze są uwarunkowane środowiskowo. Należy jednak zwrócić uwagę nie tylko na społeczności ludzkie jako część całego środowiska naturalnego, ale także na takie cechy kulturowe, które są wynikiem tych przystosowań. Steward uważał, że należy skupić się jednak tylko na tych czynnikach, którym kultury lokalne przypisują ważność. ${ }^{14}$

Steward twierdzit, że u podstaw ekologii kulturowej leży przystosowanie do środowiska, a istotnym czynnikiem jest złożoność i poziom kultury, który osiągnęła dana społeczność. Istnieje wielka różnica pomiędzy społecznościami składającymi się z myśliwych i zbieraczy działających samotnie i niezależnie, a współczesnym społeczeństwem rozwiniętym eksploatującym zasoby naturalne i wykorzystującym zaawansową logistykę i gęstą sieć transportową. W drugim przypadku, jądro kulturowe będzie determinowane przez złożoną technologię i zwyczaje..$^{15}$

Opisując ekologię kulturową, Steward wyróżnia trzy procedury leżące u jej podstaw: (1) analizę relacji pomiędzy systemem zdobywania środków do życia (subsistence system) a środowiskiem; (2) analizę wzorców zachowań połączonych z technologią używaną dla zdobycia środków do życia; (3) ocenę zakresu, w jakim dane wzorce zachowań w konkretnym systemie zdobywania środków do życia wpływają na inne aspekty kultury. ${ }^{16}$

\footnotetext{
13 J. H. STEward, Theory of Culture Change. The Methodology of Multilinear Evolution, UrbanaChicago: University of Illinois Press 1972, s. 37.

14 Por. Tamże, s. 38-39.

15 Por. Tamże, s. 39.

16 Por. Tamże, s. 40-42.
} 
Technologia obejmuje znaczącą część tego, co jest często określane jako kultura materialna. Nie wszystkie jednak czynniki są w niej jednakowo ważne. Im bardziej pierwotna jest kultura danej społeczności, tym bardziej społeczność ta zależna jest od środowiska. Wśród ważnych czynników warunkujących tę zależność należy wymienić: klimat, topografię, glebę, zasoby wodne, okres wegetacji oraz występującą tam faunę. Użycie bardziej skomplikowanych technologii zależy nie tylko od kultury i historii, ale także od środowiska i żyjącej na jego terenie fauny i flory. Wzorce wykorzystywania technologii zależą nie tylko od zwyczajów związanych z bezpośrednim sposobem uzyskiwania żywności i innych dóbr, ale także od środków transportu ludzi do źródeł zaopatrzenia lub dóbr do ich odbiorców.

Chociaż technologia i środowisko naturalne wymuszają wykonanie określonych czynności w określony sposób, to zakres, w jakim te czynności są związane $z$ innymi aspektami kultury, jest problemem czysto empirycznym. Przykładowo, występowanie patrylinearnych grup pośród niektórych ludów myśliwskich oraz podział rodzin na mniejsze grupy wśród Szoszonów Wschodnich są ściśle zdeterminowane przez sposób zdobywania przez nich środków do życia. ${ }^{17}$ Indianie Carrier są natomiast przykładem zmiany struktury społecznej bez istotnej zmiany w sposobie zdobywania pożywienia. ${ }^{18}$

Trzecia procedura składowa ekologii kulturowej wymaga autentycznie holistycznego podejścia, ponieważ jeśli takie czynniki jak demografia, zwyczaje osiedlania się, struktury pokrewieństwa, struktury własności ziemi i inne ważne czynniki kulturowe będą rozpatrywane osobno, ich wzajemnych relacji względem siebie i względem środowiska nie da się zrozumieć. ${ }^{19}$

Jednym z kluczowych elementów ekologii kulturowej jest jądro kulturowe. W rozumieniu Stewarda jądro kulturowe składa się z podstawowych cech kultury, które są ściśle powiązane z ekosystemem, a zwłaszcza podstawami gospodarczymi danego społeczeństwa i zawiera takie społeczne, polityczne i religijne wzory, które są przez ten układ determinowane. Cechy stanowiące jądro kulturowe różnią się od pozostałych (wtórnych) cech kultury, które są słabiej powiązane z jądrem i są zasadniczo zależne od czynników historyczno-kulturowych. Natomiast cechy wchodzące w skład jądra kulturowego są ze sobą wzajemnie powiązane relacjami funkcjonalno-strukturalnymi. ${ }^{20}$ Jądro kulturowe stanowiło

17 Por. Tamże, s. 41.

18 Por. J. H. STEWARD, Investigations Among The Carrier Indians in British Columbia, art. cyt. s. 280-283.

19 Por. J. H. STEWARD, Theory of Culture Change..., dz. cyt., s. 41-42.

20 Por. tamże, s. 37; por. takż J. H. STEwARD, Cultural Causality and Law: A Trial Formulation of the Developement of Erly Civilizations, "American Anthropologist" New Series Vol. 51, No. 1, 1949, s. 6-7; J. BedNARski, Jądro kultury, [w:] Z. Staszczak (red.), Slownik etnologiczny. Terminy ogólne, Warszawa-Poznań: PWN 1987, s. 166. 
ważny element ekologii kulturowej, było swego rodzaju modelem diagnostycznym służącym do empirycznego badania międzykulturowych różnic, podobieństw i regularności wśród społeczności charakteryzujących się tym samym jądrem kulturowym. ${ }^{21}$

\section{2. „Postklasyczna” ekologia kulturowa}

W późniejszych pracach Stewarda koncepcja ekologii kulturowej ewoluuje w stosunku do jej wersji z Theory of Culture Change. Ostatnią zaś jej wersję przedstawił w artykule Cultural Ecology opublikowanym w roku 1968 w International Encyclopaedia of the Social Sciences. ${ }^{22}$ Steward charakteryzuje tam ekologię kulturową jako refleksję nad procesami, poprzez które społeczność przystosowuje się do środowiska naturalnego. Głównym celem ekologii kulturowej jest ustalenie czy te dostosowania inicjują wewnętrzne transformacje społeczne czy raczej ewolucyjne zmiany. Ekologia kulturowa analizuje te zmiany w powiązaniu z innymi procesami mającymi na nie wpływ, badając jednocześnie wzajemne oddziaływania społeczności i instytucji społecznych oraz środowiska naturalnego. ${ }^{23}$ Steward porównuje ekologię kulturową z ekologią biologiczną, wskazując na ich podobieństwa w metodzie badania interakcji zjawisk społecznych i przyrodniczych w ramach danego obszaru, ale nie utożsamia cech społecznych z gatunkami biologicznymi i nie twierdzi, że rywalizacja pełni najważniejszą rolę w procesie przystosowawczym. ${ }^{24}$

Ekologia kulturowa rozpoznaje istotne różnice kultur spowodowane przez konkretne procesy przystosowawcze, poprzez które każda społeczność oddziałuje na swoje środowisko. Koncepcja ta nie zakłada jednak, że każde takie przystosowanie jest wyjątkowe i niepowtarzalne. Używając metod empirycznych, ekologia kulturowa stara się dokonać uogólnień na temat międzykulturowych podobieństw i różnic, które pojawiają się w procesach przystosowawczych. ${ }^{25}$ Ujęcie ekologii kulturowej skupia uwagę na dwóch zasadniczych kategoriach wzajemnego oddziaływania. $Z$ jednej strony jest to pewien potencjalny zespól czynników środowiskowych wyznaczony przez surowce, florę, faunę, klimat, choroby występujące na danym obszarze oraz wiele innych czynników środowiska naturalnego. Z drugiej strony są to czynniki kulturowe, szczególnie technologia eksploatacji surowców oraz technologia przystosowania do środowiska, ale także cechy swojej społeczności i społeczności sąsiednich. Oddziaływanie obu tych kategorii czyn-

\footnotetext{
21 Por. tamże, s. 166.

22 Por. J. H. STEWARD, Cultural Ecology, [w:] International Encyclopaedia of the Social Sciences, New York: Macmillan 1968, Vol. 4, s. 337-344.

23 Por. tamże, s. 337 .

24 Por. tamże, s. 337.
} 
ników (środowiskowych i kulturowych) wpływa na struktury społeczne, które są niezbędne dla prawidłowego funkcjonowania takich zjawisk jak: użytkowanie ziemi, podział dóbr, trwałość i skład struktur populacyjnych, terytorialność społeczności, stosunki miedzy społecznościami oraz wartości kulturowe czy gęstość zaludnienia. W każdym poszczególnym przypadku takiego oddziaływania powstaje jednak pytanie: czy dane przystosowanie będące konsekwencją interakcji jest tak „sztywne”, że wymusza jedynie określone wzorce, czy też istnieje możliwość rozwinięcia lub zapożyczenia pewnego zakresu potencjalnych wzorców? Wyjaśnienie tej kwestii w kategoriach ekologii kulturowej wymaga pewnych rozstrzygnięć w sposobie rozumienia kultury. Takie czynniki kultury jak technologia, język i społeczeństwo odpowiadają bardzo różnie na procesy przystosowawcze. Systemy socjokulturowe będące na różnych poziomach złożoności w różnym stopniu wpływają na interakcję czynników biologicznych, kulturowych i środowiskowych. Procesy przystosowawcze obecne w złożonych społecznościach, które wykształciły takie instytucje jak państwo i są zdolne do technologicznego oddziaływania na środowisko w skali większej niz lokalna, przebiegają odmiennie w stosunku do procesów zachodzących w społecznościach o charakterze plemiennym. ${ }^{26}$ Zaawansowana technologia społeczeństw rozwiniętych prowadzi do zmniejszenia wpływu środowiska na życie tych społeczności. W przypadku społeczeństw rozwiniętych wpływ ten jest słabszy i mniej bezpośredni niż w społecznościach pozostających na etapie rodu czy plemienia. Kultura znacząco wpływa na tworzenie swojego własnego środowiska naturalnego. Im bardziej rozwinięte jest społeczeństwo, tym lepiej jest w stanie zabezpieczyć niezbędne potrzeby swoich członków. Najlepszym przykładem tego zjawiska są stacje kosmiczne, bazy polarne czy wielkie aglomeracje wybudowane we wrogim człowiekowi środowisku. ${ }^{27}$

Steward uważa, że stosując metodę ekologii kulturowej, należy brać pod uwagę zmiany wzorców zachowań wypływające z zapożyczeń spowodowanych migracją czy procesami dyfuzji kulturowej, zawsze należy je jednak analizować pod względem zmian w stosunku do ich wzorców. Podkreśla także ważność czynników biologicznych w procesie przystosowania się i ich wpływ na wszystkie inne zmiany zachodzące we wzorcach zachowań. Wskazuje tu przede wszystkim na kwestie związane z płcią i wynikające $z$ tego różnice w rolach społecznych, wydłużanie się czasu osiągania przez człowieka dorosłości

25 Por. tamże, s. 338.

26 Por. tamże, s. 338

27 Autor wskazuje na kulturę, która ze względu na takie zjawiska jak hazard, łatwość zawierania lub rozwiązywania małżeństw czy rozrywka, spowdowała powstanie aglomeracji Las Vegas w środowisku czlowiekowi bardzo nieprzyjaznym. Por. J. H. Steward, Cultural Ecology, art. cyt., s. 342 . 
i niezależności oraz struktury rodziny. Ponadto Steward podkreśla różnice w rodzaju organizacji społecznych i osadnictwa oraz gęstości zaludnienia wynikających z czynników środowiska naturalnego (możliwości oraz znajomości upraw, obfitości i rodzaju zwierzyny, itp.). Stwierdza, że także nie-technologiczne czynniki mogą wpływać na procesy adaptacyjne przebiegające w ludzkich społecznościach. Do takich czynników zalicza, m.in. małżeństwa mieszane, handel, uczestnictwo we wspólnych ceremoniach, zawody, itp. Podkreśla też wagę czynników wynikających $\mathrm{z}$ wojen i zagrożenia oraz rolę, jaką pełnią w procesach przystosowawczych. Przykładowo, zagrożenie militarne wpływa na strukturę zabudowy osiedli ludzkich bardziej niż wynikałoby to z czynników środowiska naturalnego czy użyteczności. ${ }^{28}$

Steward uważa, że pomimo tego, iż dana kultura wytwarza całościowy system wzajemnie ze sobą połączonych elementów, jak technologia, ekonomia, struktury społeczne i polityczne, religia, język i wartości, to nie wszystkie komponenty tak rozumianej kultury podlegają jednakowemu wpływowi ekologicznego przystosowania. Komponentom związanym z kwestiami ekonomicznymi przypisuje ważniejszą rolę. W opinii Stewarda pomocą w lepszym zrozumieniu ekologii kulturowej jest ujęcie w jej świetle różnych społeczności, począwszy od prostych społeczności rodzinnych i plemiennych po najbardziej złożone społeczności państwowe. ${ }^{29}$

\section{Podsumowanie}

Porównując „klasyczną" i „postklasyczną" wersję ekologii kulturowej, widać wyraźnie, że w drugiej wersji Steward wymienia wiele czynników pozaekonomicznych, przypisując im większy wpływ na procesy adaptacyjne, niż miało to miejsce $\mathrm{w}$ wersji wcześniejszej. $\mathrm{Z}$ drugiej zaś strony w późniejszych publikacjach pomija całkowitym milczeniem koncepcję jądra kulturowego, które stanowiło istotny element wersji „klasycznej”. Odchodzi też od wcześniejszego rozróżnienia pomiędzy najważniejszymi cechami stanowiącymi jądro kulturowe oraz niezliczonymi (innumerable) cechami wtórnymi (secondary features) ${ }^{30}$ Bardziej podkreśla zaś wpływ czynników biologicznych i kulturowych na procesy przystosowawcze niż odróżnianie cech pierwszorzędnych (jądra kulturowego) i cech wtórnych kultury. Można też mieć wrażenie, że w późniejszych tekstach Steward mniej radykalnie oddziela cechy wprost łączące się z ekonomią i zdobywaniem pożywienia od tych cech, które łączą się z rytuała-

\footnotetext{
28 Por. tamże, s. 340.

29 Por. tamże, s. 342

30 Por. J. H. STEward, Theory of Culture Change, dz. cyt., s. 37;
} 
mi, stylami artystycznymi i architektonicznymi, ${ }^{31}$ którym ostatecznie przyznaje jednak pewną rolę we wpływaniu na procesy adaptacyjne danej społeczności. ${ }^{32}$ Nie bardzo wiadomo, jakim kryterium kierował się Steward, uznając, że badając procesy adaptacyjne, należy skupić się na tych cechach, które dana kultura uznaje jako ważne. ${ }^{33}$ Można sobie bowiem wyobrazić, że jakiś zwyczaj, który w danej kulturze nie jest uznany za istotny, stanowi warunek sine qua non bytu danej społeczności. ${ }^{34}$

Odejście od koncepcji jądra kulturowego posiada dalekosiężne konsekwencje. Kwestionuje to bowiem wprowadzoną przez Stewarda typologię kultur, co z kolei wpływa destrukcyjnie na wieloliniową ewolucję kultury. Moźna mieć wątpliwości, czy Steward zdawał sobie sprawę ze wszystkich konsekwencji odejścia od koncepcji jądra kulturowego. ${ }^{35}$ E. Morgan, krytykując Stewarda, zarzuca mu, że wprowadzając jądro kulturowe, pomniejsza ważność zakresu, złożoności, zmienności i misterności zarówno środowiska naturalnego, jak i systemów społecznych. ${ }^{36}$ Odejście jednak od tej koncepcji powoduje, że ekologia kulturowa stała się bardzo ogólna i straciła swą wyrazistość, choć nadal pozostała atrakcyjną metodą w badaniu zmian zachodzących w różnych społecznościach.

Z całą pewnością Steward miał wyraźną świadomość, że ekologia kulturowa nie jest w stanie dostarczyć „niezachwianych wyjaśnieñ" procesów społecznych. Nigdy nie twierdził także, że jest ona jakąś teorią, wręcz przeciwnie zwykle określał ją mianem metody, zagadnienia, podejścia czy ujęcia procesu zmian zachodzących w społecznościach ludzkich. Steward był stanowczym wrogiem wszelkich ideologii i każdy „izm” był dla niego czymś obcym, dlatego nie traktował ekologii kulturowej jako kolejnego „izmu”.37 $\mathrm{Na}$ dwa lata przed śmiercią napisał: „Nigdy nie miałem intencji, by wyjaśnienia ekologiczne lub jakiekolwiek korelacje pomiędzy kulturą a środowiskiem były wyjaśnieniami niezachwianymi". ${ }^{8}$ Traktował je raczej jako hipotezę umożliwiającą analizę danych empirycznych, która jest bardzo użyteczna w przedstawianiu przyczyn zmian zachodzących w kulturze.

\footnotetext{
31 Por. J. H. STeward, Cultural Ecology, art. cyt., s. 339.

32 Por. tamże, s. 340.

33 Por. J. H. STeward, Theory of Culture Change..., dz. cyt., s. 39.

34 Przykładem takiej sytuacji może być np. wyrabianie naczyń z metali, które szkodliwie działają na ludzki organizm.

35 Por. V. Kerns, Scenes from the High Desert..., dz. cyt., s. 303.

36 Por. E. F. Moran, Ecosystem Ecology in Biology and Anthropology: A Critical Assessment, [w:] E. F. Moran (red.), The Ecosystem Approach in Anthropology. From Concept to Practice, Ann Arbor: The University of Michigan Press 1993, s. 10.

37 Por. V. Kerns, Scenes from the High Desert..., dz. cyt., s. 310.
} 
Steward przynajmniej po części zdawał sobie sprawę z konieczności przemyślenia na nowo całej koncepcji ekologii kulturowej. Zabrał się nawet do pracy nad rewizją Theory of Culture Change, niestety śmierć przerwała jego wysiłki. Jane C. Steward, żona i długoletnia osobista sekretarka Juliana Stewarda, próbowała po śmierci męża dokończyć rozpoczętą pracę. Niestety Steward, pracując nad kolejnym wydaniem książki, przyjął metodę przepracowywania konkretnych zagadnień a nie rozdziałów. W kolejnym kroku miał się zająć uzupełnieniem i poprawieniem poszczególnych części książki. Ze względu na trudności i brak dostatecznej wiedzy na temat ostatecznych rozstrzygnięć co do kierunku zmian Jane Steward odstąpiła od pomysłu dokończenia pracy męża. ${ }^{39}$

Wydaje się, że zaproponowana przez Stewarda koncepcja ekologii kulturowej pozostawia wiele do życzenia. W publikacji z roku 1968 Steward ani słowem nie wspomina "trzech procedur" stanowiących serce ekologii kulturowej, chociaż w roku 1955 określał je jako „fundamentalne” dla swojej koncepcji. ${ }^{40}$ Późniejsze opracowania ekologii kulturowej wracają jednak do pewnych konkretnych i ściśle określonych elementów ekologii kulturowej. Richard O. Clemmer, analizując koncepcję Stewarda, odchodzi od trzech procedur, które w myśl Stewarda miały stanowić podstawę ekologii kulturowej. Na ich miejsce Clemmer wprowadza jednak aż sześć kategorii zmiennych, które wzajemnie na siebie oddziałują: (1) zasoby środowiska naturalnego; (2) technologia używana, aby te zasoby wydobyć, przetworzyć i przechować; (3) społeczna i polityczna organizacja produkcji, ochrony, przeznaczenia i podziału zasobów oraz organizacja ludzkiej pracy dla ich uzyskania; (4) kultura połączona ze wszystkimi powyższymi czynnikami, włączając w to wartości ekonomiczne i wzorce zachowań; (5) biologiczna natura istoty ludzkiej oraz (6) procesy psychiczne i dążenia człowieka. ${ }^{41}$

Wydaje się, że prezentacja ekologii kulturowej z roku 1968 ma niewiele wspólnego, z tą z roku 1955. Zamiast konkretnych wskazań na temat ekologii kulturowej jako metody, Steward zaoferował pewne ogólniki na temat wzajemnej relacji pomiędzy kulturą a środowiskiem naturalnym. Rezygnując natomiast z jądra kulturowego, zakwestionował pozostałe swoje koncepcje dotyczące rozwoju i typologii kultury. Z niezrozumialych też względów pominął „procedury” stanowiące podstawę pierwotnej wersji ekologii kulturowej.

38 Por. tamże, s. 302.

39 Por. tamże, s. 311.

40 Por. J. H. STEward, Theory of Culture Change..., dz. cyt., s. 40.

41 R. O. Clemmer, Steward's Gap: Why Steward Did Not Use His Theory of Culture Change to Explain Shoshoni Culture Change [w:] R. O. Clemmer (red.), L. D. Meyers (red.), M. E. Rudden (red. ), Julian Steward and the Great Basin. The Making of an Anthropologist, Salt Lake City: The University of Utah Press 1999, s. 153. 
Ekologia kulturowa spotyka się także z krytyką, iż jest jednostronnym ujęciem relacji natury i kultury, koncentruje się bowiem na materialnej sferze kultury i jej wpływie na środowisko naturalne. Niemal zupełnie pomija natomiast sferę sztuki, magii, wartości, wierzeń czy symboliki. Można też mieć wrażenie, że nawet w sferze „ekonomicznej” Steward pominął niektóre kwestie. Zbyt łatwo zdyspensowal się z analizy roli i wkładu kobiet i dzieci w kształtowanie się wzajemnych interakcji kultury i natury, co stało się przyczyną krytyki jego stanowiska przez środowiska feministyczne. Koncentracja na aspekcie ekonomicznym pozostawiła na boku takie sfery życia społecznego, jak choroby, reprodukcję czy politykę, które również stanowią przestrzeń mechanizmów dostosowawczych społeczeństw ludzkich.

Podtrzymywane do dzisiaj żywe zainteresowanie ekologią kulturową najlepiej świadczy o tym, że pomimo swych braków, koncepcja Stewarda jest wciąż atrakcyjną metodą w dochodzeniu do zrozumienia zmian w społecznościach ludzkich. Koncepcja ta domaga się jednak dalszej analizy krytycznej, uwzględniającej osiągnięcia antropologii współczesnej. Liczne grono uczniów i naśladowców Stewarda nadal stosuje i rozwija jego koncepcję, czego dowodem są liczne publikacje z tego zakresu.

\title{
Evolution of Julian Haynes Steward's Concept of Cultural Ecology
}

\author{
SUMMARY
}

Julian H. Steward is the author of anthropological approach called cultural ecology. Steward had been working on the concept for about forty years and used that approach in both his theoretical and field works. The version of cultural ecology presented in his most famous work Theory of Culture Change (1955) is significantly different than the form of the approach published in 1968. The goal of this essay is to present evolution in Steward's understanding of cultural ecology, and to show the differences between the two main versions of the approach. The main difference between them is the disaperence of cultural core and three procedures - ideas which were the basis of the earlier form of cultural ecology. Changes in Steward's approach caused problems for his other concept, especially for multilinear evolution of culture and the concept of types of culture. 